\title{
XXVII. On the remarkable fossil trees lately discovered near St. Helen's
}

\section{E.W. Binney}

To cite this article: E.W. Binney (1844) XXVII. On the remarkable fossil trees lately discovered near St. Helen's, Philosophical Magazine Series 3, 24:158, 165-173, DOI: 10.1080/14786444408644828

To link to this article: http://dx.doi.org/10.1080/14786444408644828

册 Published online: 30 Apr 2009.

Submit your article to this journal $[\pi$

Џ Article views: 5

Q View related articles $\square$ 
pole. On this it was observed, that the iodine would form iodic acid with the oxygen coming from the starch solution in the opposite direction, and so not appear in a free state. I answer, if so, why did not the iodine ultimately appear at the negative pole, and there affect the starch, seeing that the newly-formed iodic acid would be as liable to direct decomposition as the original? Again, if bromide of iodine was directly decomposed, why was there effervescence at the positive pole, and why was not an orange compound of bromine and starch formed at that pole?

Analogous views are applicable to the decomposition of the hydracids, and were formerly sufficiently explained*.

As to the observation on my argument for the solution of haloid salts as hydracid salts, that the acid and alkali formed in the circumstances mentioned + might have arisen from the union of the elements of the haloid with those of water, it is plain that this view assumes that haloid salts, supposing them to be dissolived as such, are directly decomposed by the current, whereas it was established by evidence of exactly the same kind, as in regard to hydracids, that the electro-negative element appearing during their decomposition has a secondary origin. But further, supposing this had not been established, on what grounds can we assume that if the haloid is dissolved as such, and directly decomposed, the hydracid supposed to be formed by the subsequent union of the electro-negative element with hydrogen shall not be equally directly deconuposed? and if so, how can we have any acid to detect, far less a constantly accumulating quantity of it?

St. Andrews, January 27, 1844.

XXVII. On the remarkable Fossil Trees lately discovered near St. Helen's. By E. W. Binney, Secretary of the Manchester Geological Society $\ddagger$.

DROBABLY no fossil plant has excited more discussion among botanists than the Stigmaria. It is the most common of the whole number of plants found in the coal measures, but there has hitherto been the greatest uncertainty as to its real nature. In the Lancashire coal-field traces of it may be found in every mine. It abounds in all the floors of the coals unmixed with any other plants, and having the long stringy fibrils hitherto considered as leaves radiating from the stem in all directions, and often the fibrils alone are seen without

* See p. 246-7 of the memoir in this Journal above referred to.

+ See p. 357, \&c.

I Communicated by the Author; having been read before the Manchester Geological Society, October 26, 1843. 
the stem. On careful observation it is also to be found in the upper and lower portions of most of the seams of coal, generally with its stringy appendages. It is also more rarely met with in the roofs of coal mines and in sandstone rocks. The specimens in the floors are by far the most numerous, and they are frequently found to strike down from the lower part of the coal into the clay underneath; sometimes, where this deposit is a thick one, at a considerable angle, and when it is thin, nearly horizontal.

Among the many authors who have written on this plant, probably no one has shown so accurate a knowledge of it as Mr. Steinhauer. In an elaborate paper printed in the first volume of the new series of the American Philosophical Transactions, he describes the most perfect form of the fossil as that of a cylinder more or less compressed, and generally flatter on one side than the other. Frequently the flattened side turns in so as to form a groove. The surface is marked in quincuncial order with pustules, or rather depressed areolæ, with a rising in the middle, in the centre of which rising a minute speck is often observable. From different modes and degrees of compression, and probably from different states of the original vegetable, these areolæ assume very different appearances, sometimes running into indistinct rimæ like the bark of an aged willow; sometimes, as in the shale impressions, exhibiting little more than a neat sketch of the concentric circles. He was of opinion that the fibrous processes, acini, spines, or whatever else they might be called, were cylindrical, and that small fragments of these cylinders showed distinctly a central line of (pith?) coinciding with the point in the centre of the pustule, and that some of these extender to the length of twenty feet. He also notices the groove of the cylinder being always under, and suggests that the pith had fallen down from the centre; and after further details he concludes, "that the stem was a cylindrical stem or root growing in a direction nearly horizontal in the soft mud at the bottom of freshwater lakes or seas, without branches, but sending out fibres from all sides; that it was furnished in the centre with a pith of a structure different from the surrounding wood or cellular substance, more dense and distinct at the older end of the plant, and more similar to the external substance towards the termination which continued to shoot; and perhaps that besides this central pith there were longitudinal fibres proceeding through the plant like those of the roots of Pteris aquilina. With respect to any stem arising from it, if a creeping trunk, we have hardly ground for a supposition."

Messrs. Lindley and Hutton, after noticing at great length 
Steinhauer's remarks in vol. i. p.106 of their Fossil F'lora, come to the following conclusions:-1st. That the Stigmaria was a prostrate land plant, the branches of which radiated regularly from a common centre, and finally became forked; 2 nd, that it was a succulent plant; 3rd, that it was a dicotyledonous plant; 4th, that the tubercles on the stem are the places from which the leaves have fallen; 5 th, that the leaves were succulent and cylindrical. These authors, in their introductory chapter of the second volume of their work, after stating that they had seen two very perfect specimens found in the roof of the Bensham seam of the Jarrow colliery, state that the centre of the plant was a continuous homogeneous cup or dome, and not the remains of the arms squeezed into a single mass, as they had formerly surmised it might be; and also that it was not, as they before supposed, a land plant, but that it grew in soft mud, most likely of still and shallow water, as they had found its remains associated with an undescribed species of Unio.

In the year 1839 , in company with the Rev, Robert Wallace, F.G.S. and Mr. Atkinson, I examined some upright specimens of the stems of Sigillaria reniformis found resting upon a small seam of coal exposed in cutting the tunnel at Clay Cruss, on the North Midland Railway near Chesterfield. I there distinctly traced a Stigmaria to the lower part of a Sigillaria; not being able positively to prove the absolute insertion of one plant into the other, I was not able to pronuunce with certainty that they were portions of the same tree, but I was convinced that Messrs. Lindley and Hutton had been mistaken in supposing that the Stigmaria was a domed or cupshaped plant, and that it had no upright stem. Accordingly, in my paper read by me in 1840 on the Fossil Fishes of the Pendleton Coal-field, at p. 178 in the first volume of the Transactions of the Manchester Geological Society, I state that the Stigmaria grew in water on rich mud, in a bay like the recent mangrove of the tropics at the mouth of the Niger in the Brass country. For the last four years I have examined a great number of upright Sigillariæ for the express purpose of acquiring a correct knowledge of their roots.

Many practical colliers having seen upright stems of Sigillarix with part of their roots on small seams of coal only eight to twelve inches in thickness, the floors of which were full of root-like Stigmariæ, very naturally concluded that the latter were the roots of the former. M. Adolphe Brongniart has lately announced that he supposed the Stigmaria would turn out to be the root of the Sigillaria, from the great similarity in their internal structure. Some geologists have also made si- 
milar guesses, but to my knowledge their opinions received little consideration, owing to their not being able to bring any facts in support of them.

The three fossil trees in the accompanying section, which it is my intention to describe, were exposed to view during the last summer in the White Grit Quarry belonging to Mr. Littler, at Scotch-row, near St. Helen's. They were met with in removing the gray indurated silty clay, there known by the name of "warren," a deposit nearly similar to many coal-floors, for the purpose of working the sandstone lying under it. The surface is covered with from six to eight feet of brownish coloured till, under which the warren containing the fossil trees occurs. This latter deposit was exposed about seven yards in thickness, and the white grit lying under the workmen informed me was ten yards thick. The inclination of the strata is to the east at an angle of about $23^{\circ}$. All the trees were at right angles to the strata, and stood in a line nearly north and south, about eight feet six inches above the grit rock, and continued upwards until cut off by the till.

Section of Mr. Littler's Quarry, near St. Helen's.

Surface.

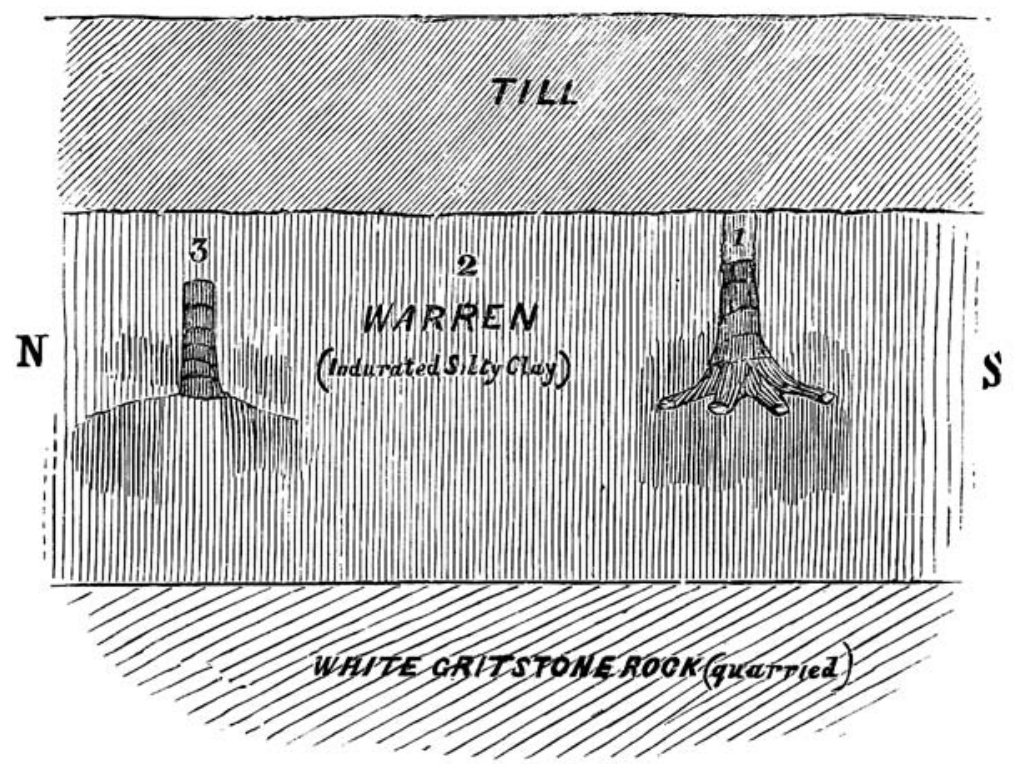

Note.-This imperfect sketch is intended to give the reader merely an idea of the position of the trees, and not to show their external characters.

The strata in which the fossils are met with occupy the 
lower part of the middle Lancashire coal-field, about 119 yards above the Rushey-park mine, the last thick seam in the series, and between two beds of coal, the Sir Roger and a yard mine.

By the kindness of my friend, Mr. John Hawkshead Talbot, I am enabled to give the following section showing their position :-

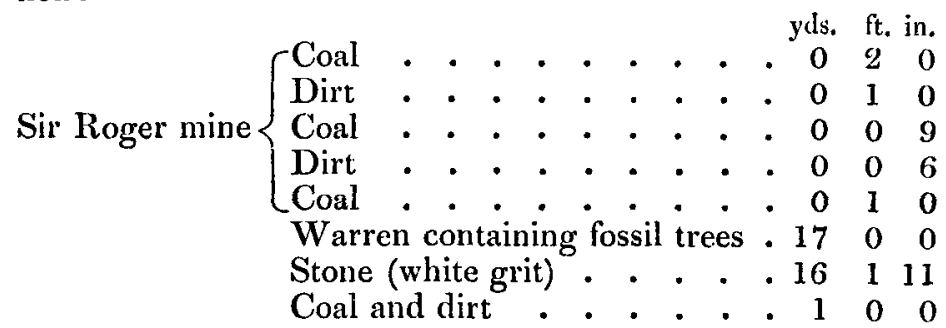

When I visited the place the trees had been exposed some time, and hundreds of people had inspected them. They appear to have been the wonder of the neighbourhood, and excited not only considerable interest, but an unfair share of cupidity. The proprietor of the quarry was anxious to preserve them, and gave such orders to his servants ; but although placed in a perpendicular wall of rock, parties provided with ladders came during the night twice and stole portions of the roots.

Three specimens were originally standing in the quarry, but the centre one has been removed. No. 1 , the tree on the south side of the quarry, is considerably the largest, and displays roots which Nos. 2 and 3 did not do to an unpractised eye.

Both the gritstone rock and the indurated silty clay in which the fossils were found afforded specimens of Lepidodendron, Calamites, Pecopteris nervosa, a Neuropteris, and several other coal plants.

The diameter of the largest specimen, No. 1, at the base is about two feet nine inches, and at the top about one foot two inches. Its height is now near seven feet*, but the workmen informed me that two feet had been taken of the top, so that it originally was about nine feet high. Scarcely one half of the tree is exposed, the other half being still encased in the matrix, in which it is imbedded. Four main roots have been uncovered; these evidently spring from the base of the tree in pairs, like the roots of the trees found at Dixon Fold, on the Manchester and Bolton Railway. Two of the roots had been removed before I saw them, with the exception of about eight inchesfrom their commencement, but the third I traced fourteen

* These dimensions are not from absolute admeasurement, there being difficulties in the way which prevented me from taking such. 
inches, and the fourth about two feet. The workmen assured me that they had measured the four roots full nine feet from the stem. All the roots are coated with a slight covering of bituminous coal, which adheres to the matrix in clearing them, so that they all appear decorticated. Their surfaces are of a blackish colour, and marked with ribs and furrows which diverge on each side of lines which are parallel with the longitudinal axis of the root, a peculiar character noticed by my friend, the late Mr. Bowman, in the roots of the Dixon Fold trees. Although the roots I examined were on the rise of the strata, they struck down into the indurated clay at a greater angle than those at Dixon Fold. The root on the south of the stem was the one I first examined; on inspection I noticed the fibrils, so long considered as the leaves of the Stigmaria, proceeding from it in all directions, but more numerously from the under than the upper side. On looking at the matrix on which the continuation of the root had laid, I found the areolæ with a little elevation in the centre, the convex corrugated lines so common to large Stigmaria and the central pith, which had evidently sunk down and formed a groove in the matrix. The fibrils or radicles were all flat and showed something like a central axis-some of them were measured-upwards of three feet below the stem, and others, although not absolutely proved to be continuous, could be traced eight and nine feet down. Indeed, the whole of the shale lying between the base of the tree and the top of the white rock was traversed by these fibrils or radicles proceeding from the main roots. I did not notice any entering into the rock itself. Immediately under, but I could not see it join the tree, proceeded a stem like a tap-root, about $2 \frac{1}{Q}$ inches in diameter and inclining a little to the north; it was about two feet long, but owing to my being able only to examine the mould, I could not make out its characters. The north root I carefully cleared from the matrix to the extent of near two feet, and found the radicles to proceed from the main root in all directions, but stronger and more numerously from the under side of it. In addition to these, I found a circular tapering root of about an inch in diameter proceeding in a straight line. I attempted to obtain a portion of the root with the bark upon it, but I could not succeed, the coaly envelope always adhering to the matrix and leaving the root decorticated.

Notwithstanding that I carefully examined the stem of No. 1 four feet upwards, I could not distinguish the scars so generally found on Sigillaria. The trunk was decorticated, with the exception of some small specks of coal, and was marked with irregular ribs, slightly convex, and parted by shallow and 
narrow irregular furrows. Some of the ribs and furrows divide and unite without order, and are marle up of detached portions having wavy and diagonal directions, which mix, become faintly visible, and finally disappear. Impressions of the ribs were taken on tracing-paper, and they exactly correspond in character to those of the Dixon Fold trees.

No. 2 specimen had been removed from the quarry when I first visited the place. The workmen informed me that they had noticed no roots belonging to it. It is now lying in the adjoining quarry in fragments, and appears to have been about fifteen inches in diameter and nearly cylindrical. The interior of it is composed of a very fine-grained hard stone, which, although not what is generally called a sandstone, has more sand in it than the matrix in which it was imbedded, and I did not notice any internal cylinder so often met with in these upright stems, but one of the sides presented a longitudinal depression. The exterior exhibited the scars, ribs, and furrows generally found on the Sigillaria reniformis so distinctly, that there could be no doubt of its being one.

No. 3 is still standing in its original position in the quarry; it appears to be about eight feet above the sandstone, and four feet of it are exposed to view, the upper part being still covered with clay. The base of it does not plainly show the main roots like No. 1, but on cutting down the face of the clay under it, although the roots had disappeared, I distinctly traced the fibrils or radicles, similar to those of No. 1, radiating from the centres, where the roots formerly were, in all directions. From its exposed parts I take it to be about ten inches in diameter; it is decorticated, and seems to have been cylindrical. I could not see very well-defined scars upon its surface, but its ribs and furrows prove it to be a Sigillaria.

On examining the matrix near the stem I observed several grass-like fibres, resembling the supposed leaves of the Lepidodendron, running horizontally from it, but as I could not distinctly trace their insertion, I will not take upon myself to pronounce them leaves, although they were very like those supposed to be such by my friend Mr. M. Dawes, F.G.S., in one of his specimens now in the museum of the Manchester Geological Society. At some future time, when the tree is more exposed, I shall be able to give a more decided opinion on this subject.

In conclusion I may state, that there is no question as to the perfect identity of No. 1 specimen with No. 5 at Dixon Fold, which the late Mr. Bowman, after a very careful examination, pronounced to be a decorticated Sigillaria. I am aware that 
the correctness of this opinion of my late friend has been questioned by some eminent authorities nevertheless; after having examined many large specimens of upright Sigillariæ, I am led to believe that the lower portions of very old trees, when decorticated, do not exhibit those regular ribs, furrows, and scars so characteristic of young specimens, and that he was perfectly right in his supposition. No. 2, a lesser specimen than No. 1 , is an undoubted Sigillaria reniformis, but it gives no more evidence of being allied to No. 1 than having been found near it. No. 3 is also a Sigillaria, and the main roots have almost disappeared, but its fibrils or radicles radiating from the places formerly occupied by them, are most certainly of the same kind as those of No. 1 . Therefore, if similarity of fibrils or radicles is any evidence of identity, No. 1 must be decided to be a Sigillaria.

In addition to this I may state, that the upright stem before described as found at Clay Cross, was an undoubted specimen of Sigillaria, and the root traced to it a Stigmaria.

Having thus described the upper portions of these trees, let us now consider their extremities. With regard to the roots of the specimens being Stigmariæ, there might be a reasonable ground to doubt it, if the fibrils were the only evidence of the proposition; but when we find that not only are the fibrils the same, but the areolæ and the central pith, in fact the whole of the characters of the Stigmaria attached to the root, there can scarce exist a doubt upon the subject.

The stems Nos. 1 and 3, being only partially exposed, have not been examined for the purpose of noticing those concave depressions so generally found in upright Sigillariæ, and which Mr. Bowman suspected might have been made by some parasitical plant, but which it is probable were really caused by the change in the position of a central woody axis. No. 2 displays it, although the internal cylinder, which, by its removal from the centre, caused the depression to take place, cannot now be seen, as is generally the case, without breaking the specimen vertically. These internal cylinders in the centre of upright Sigillariæ have not been described with the attention that is due to them, and cannot have escaped the attention of collectors. They are not often to be seen in coarse sandstone casts, but are rarely absent in those of indurated clay when carefully looked for, and when the cylinders have not been filled up with masses of leaves and other parts of plants. In a specimen of Sigillaria from Clay Cross, I have a cylinder with its outside coated with carbonaceous matter and resembling the cast of the exterior of the stem of a common calamite or Endo- 
genites striata, I cannot positively say which.; Now, although it would not be safe to pronounce on a single specimen that one of these hitherto supposed plants was an internal stem, still, as we have seen that the Stigmaria and Sigillaria have so long passed for distinct plants by the most eminent living botanists, we must not look to the opinions of men, however distinguished, but rather trust to the collection of facts before hazarding an opinion. The authors of the Fossil Flora, in p. 24, vol. iii. of that work, in describing the fossils of Burdiehouse, notice the rarity of Calamites, the almost entire absence of Stigmaria, and that they did not find Sigillaria. In my own experience I have always found Calamites associated with Sigillaria, and Stigmaria constantly present with them either in the roof or floor.

The Stigmaria or Sigillaria, whichever name is to be retained, and probably the latter is the most proper, was a tree that undoubtedly grew in water, for the indurated silty clay in which the specimens described in this paper occur was deposited from that medium, and the position of the roots and radicles, ramifying through the strata in all directions, prove that they grew there, and preclude the possibility of their ever having been transported to the place where they are now found. The position too of the trees, placed as they are about midway between two seams of coal, $33 \mathrm{yds} .1 \mathrm{ft}$. 11 ins. distant from each other, proves that, however gradually the bottom of the water may have subsided, still that the trees grew and flourished, notwithstanding that very considerable portions of the stems were submerged in water. This singular position of large trees is very interesting; physiological botanists will now probably be enabled to throw some light on the functions of those fibrous appendages which proceeded from the furrows of the stems of Sigillariæ, and which may have assisted to nourish these most extraordinary trees.

* In this specimen the internal cylinder is the only vegetable matter in the inside of the stem, and there can scarce be a probability of its having been introduced, as is sometimes the case when Calamites are found mingled with many other plants.

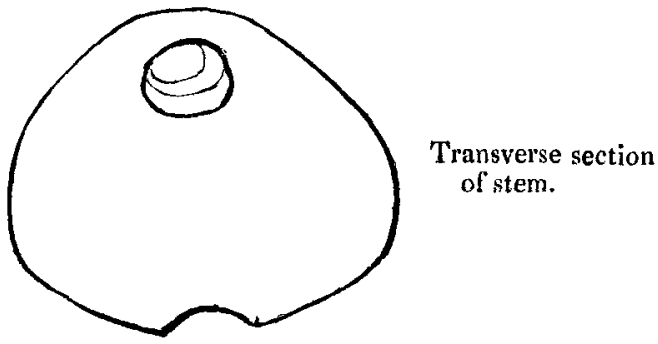

